\title{
Études sur la Correspondance de Synésios de Cyrène by Denis Roques
}

Jacqueline Long

Loyola University Chicago, jlong1@luc.edu

Follow this and additional works at: https://ecommons.luc.edu/classicalstudies_facpubs

Part of the Classics Commons

\section{Recommended Citation}

Long, J. (1991). "Études sur la Correspondance de Synésios de Cyrène by Denis Roques." Classical Philology, 86(4): 357-364.

This Book Review is brought to you for free and open access by the Faculty Publications and Other Works by Department at Loyola eCommons. It has been accepted for inclusion in Classical Studies: Faculty Publications and Other Works by an authorized administrator of Loyola eCommons. For more information, please contact ecommons@luc.edu.

\section{(c) $($ () $\ominus$}

This work is licensed under a Creative Commons Attribution-Noncommercial-No Derivative Works 3.0 License. (c) University of Chicago Press, 1991. 
authors about the virtues of the countryside and the enervating effects of urban life (e.g., Tac. Agricola 21) are neglected: there is no space for evidence in two pages of assertions about changing attitudes to cities from the classical era to the nineteenth century. It is claimed further that "no [sc. urban-rural] conflicts are mentioned in ancient sources" (p. 136), without regard to the second chapter of R. MacMullen's Roman Social Relations, 50 B.C.-A.D. 284, which quotes ancient authors on just this subject. The conclusion moves rapidly on to an intellectual history of the twentieth century (in five pages), beginning with anti-colonial movements in the 1920s and ending with Pol Pot's genocide in Cambodia: in their hostility to parasitical cities, Finley's Ancient Economy and Pol Pot come out of the same misguided intellectual tradition.

Finally, it must be said that the editing of this book leaves much to be desired. There are grammatical mistakes that no high-school student should make: a verb that does not agree in number with its subject (p. 69); a pronoun without an antecedent (p. 116); and "an vast range ..." (p. 125). Proofreading reaches its nadir on page 32, with an equation that is mathematical nonsense. Entries in the index are out of alphabetical order (p. 260). A higher standard is to be expected from a major university press.

In sum, this book seems to me to represent an opportunity wasted. The idea of using Roman Corinth as a starting point for an economic analysis of the Roman Empire is promising. To say that Corinth, as a nodal point for Mediterranean trade, was not simply a consumer city is only to begin the analysis of its place in the imperial economy. E.'s attempt to take into account the value of urban services raises interesting questions-how much did the pure water supply reduce mortality, and for what groups?-but his analysis is not sufficiently rigorous to yield answers. In a sense this book is premature: work on the site, carried out annually by C. K. Williams for the American School of Classical Studies at Athens, is just now progressing to the point where informed accounts of residential patterns and urban activities will soon be possible. ${ }^{10}$

Richard P. Saller

The University of Chicago

10. I appreciate the help of Elizabeth Gebhard, especially her advice on the state of archaeological work at Corinth.

Études sur la Correspondance de Synésios de Cyrène. By Denis RoQues. Collection Latomus, 205. Brussels: Latomus-Revue d'Études Latines, 1989. Pp. 274 + 3 figs. (fold-out maps); 3 tables in text. FB 1,300 (paper).

Chronology is a science of minute questions and seemingly picayune distinctions, compared to the grander concerns of history, literature, or the personality of an ancient author. But as Roques emphasizes, interpretive problems should be addressed within a solid objective framework, such as chronology establishes (pp. 6, 235). This volume presents studies that R. carried out preliminary to his Synésios de Cyrène et la Cyrènaïque du Bas-Empire (Paris, 1987). In fact Synesius' writings 
are not limited in significance to himself and Cyrenaica: they illuminate literary, philosophical, religious, political, and historical issues of the later Roman Empire as a whole. R.'s thorough, detailed study should bear upon any research that makes use of them. Unfortunately, flaws both in his primary assumptions and in his method of proceeding from them drastically limit the usefulness of his conclusions.

R. observes that only three dates within Synesian chronology directly align with external evidence by which they can be determined absolutely: Synesius' embassy to Constantinople, the beginning of the barbarian war in Pentapolis, and the Easter date fixed by Epistle 13 (p. 17). Scholarly consensus hitherto has worked within these limits gingerly, fixing major events of Synesius' life often no more closely than to years or ranges of years (p. 9). R. in contrast dates virtually everything, sometimes to exact days and usually to months or quarter-years. In successive chapters he deduces relative chronologies for coherent groups of Synesius' letters. He links the groups with his fixed dates in order to establish other dates absolutely. These dates in turn help fix others. R. organizes his discussion by argumentative logic rather than chronological order, but avoids confusion by carefully subdividing his argument, frequently recapitulating his conclusions, and summarizing them in a most helpful array of tables and indexes (pp. 247-74). R. discusses all Synesius' letters and dates except the most exiguous aphorizing scraps. He also dates the essays De regno, De providentia, and Dion, ${ }^{1}$ as well as the crucial events of Synesius' life: his birth, his marriage, the births of his children, the war in which he participated against barbarian invaders of Libya, his ordination, the deaths of his children, his excommunication of Andronicus, and his own death.

R. relies on Terzaghi's editions of Synesius' hymns (Synesii Cyrensis Hymni [Rome, 1939]) and essays (Synesii Cyrensis Opuscula [Rome, 1944) and Garzya's edition of Synesius' letters (Synesii Cyrensis Epistolae [Rome, 1972). ${ }^{2}$ All textual questions must be referred to the editions, whether or not R. gives explicit notice. ${ }^{3}$ The reader will be obliged to doublecheck back through several layers of R.'s cumulative arguments.

R. (p. 17) follows O. Seeck in dating Synesius' embassy to the years 399-402. ${ }^{4}$ The basic argument is straightforward. Synesius at Hymn 1. $428 \mathrm{ff}$. and Insomn. page 175. 16-18 says that he spent three years in Constantinople, and at Epistle 61 page 101. 1 that he departed during an earthquake; Chron. Marc. s.a. 402 attests an earthquake: therefore Synesius departed in 402 and arrived during 399. Seeck was forced to emend away the fact that Synesius calls Aurelian "consul"

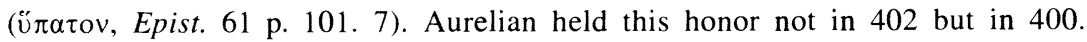
C. Lacombrade (followed by Garzya and hence, tacitly or unawares, by R.) tried

1. R. promises to study Synesius' Hymns in the future (p. 162, n. 8).

2. So do the citations in this review. R. conveniently appends a concordance between Garzya's and the other three systems of numeration in which Synesius' letters are found (pp. 253-54).

3. R. gives references without additional explanation at p. 168, n. 63, concerning Epist. 120 p. 205.10 ,

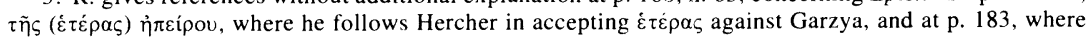

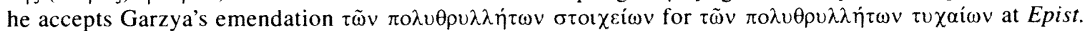
5 p. 20. 9-10. But he gives no reference, for example, at p. 220 where he identifies Alexander by inter-

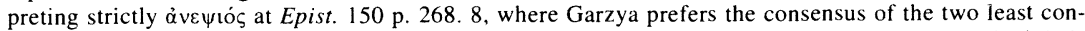
taminated MSS to others' $\dot{\varepsilon} \xi \alpha v \varepsilon \psi$ tóc. (cf. Garzya, Synesii Cyrensis Epistolae, p. lxi). Garzya's principle is sound, but it does not appear that R. has considered the question.

4. "Studien zu Synesius," Philologus 52 (1893): 442-83, esp. pp. 458-60, 462. 
to escape emending a sound text by suggesting that Synesius might have deliberately mistitled Aurelian in order to impress his correspondent Pylaemenes. ${ }^{5}$ But the Constantinopolitan Pylaemenes would have been less impressed by Aurelian's outdated title than shocked at Synesius' abuse of formal titulature. It is easier to believe that a later chronicler missed or misdated an earthquake, within a period of a few years when several different earthquakes shook Constantinople (cf. p. 201), than that Synesius made a gross error of protocol. Indeed Alan Cameron has recently shown that the Homilies on Acts of John Chrysostom confirm that Constantinople did suffer an earthquake in 400 . The texts conform, without emendation: Synesius left in 400, so he must have arrived in $397 .{ }^{6}$ Confirmingly, T. D. Barnes $^{7}$ and P. J. Heather ${ }^{8}$ have demonstrated that Synesius' De regno evokes political situations of 397/98 (pace, most recently, R., pp. 235-43).

R. dismisses Cameron without making any adequate counterargument (p. 19, n. 26). Although there is, as he observes, room for doubt about when some of the Homilies on Acts were delivered, Cameron dates the main body of them to 401 convincingly enough for purposes of his argument. Second, R. asserts that it is methodologically preferable to rely on an ancient text of certain dating than on modern argumentation, however well documented. But Cameron does not substitute a conjectural argument for an ancient dated text. Epistle 61 dates itself explicitly; Cameron shows that Seeck associated the wrong text with it, and that the letter's own evidence is confirmed by other sources. ${ }^{9}$ Even R. abashedly concedes, with a parenthetical question mark in his summary of Seeck (p. 17), that Cameron decisively rebuts Seeck's attempt to redate the homilies to John's priesthood in Antioch. If this evidence can no longer be dismissed, Seeck's case is at least seriously weakened. R. does nothing to reestablish it. Nor can he have reflected that his prim objection opposes the methodology of his own book, inappropriately. It is by modern argument that we determine the date of any ancient text to be certain. Finally, R. repeats that Synesian chronology must be founded on the aggregate of the letters. But the earthquake is not a contingent element in the chronology of Synesius' life and works, datable only by reference to other, fixed points. It is one of the three fundamental fixed points on which the edifice of R.'s chronology stands. Mere internal consistency cannot give a derivative structure the power to validate one of its own foundations.

This initial error invalidates most of R.'s absolute dates. Simply shifting them two years cannot repair his chronology, for many factors combine with the date of

5. Synésios de Cyrène, hellène et chrétien (Paris, 1951), p. 101, n. 5.

6. "Earthquake 400," Chiron 17 (1987): 343-60.

7. "Synesius in Constantinople," GRBS 27 (1986): 93-112.

8. "The Anti-Scythian Tirade of Synesius' de Regno," Phoenix 42 (1988): 152-72. R. does not register this article.

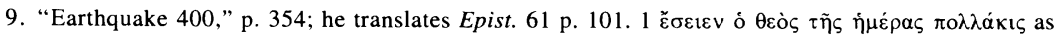
"[God shook the earth] repeatedly during the day," and finds that this phrase conforms with the apparently short duration of John's earthquake (cf. Homily 41 on Acts, PG 60. 201). R. (p. 98), however, translates, "Diéu ébranlait la terre fréquemment chaque jour." The article with ij $\mu \varepsilon \varepsilon_{\alpha} \varsigma_{\varsigma}$ may create this distributive sense (cf. H. W. Smyth, Greek Grammar, rev. G. M. Messing [Cambridge, Mass., 1956], $\S 1445$ ), but the article may be explained on the other interpretation by the fact that a specific day is in question (cf. Smyth, \$1444). Both translations are grammatically possible. But Synesius describes himself fleeing the city, because of the earthquake, too hastily to make all the proper arrangements: it seems unreasonable to assume that he waited through several days' tremors. 
the embassy to limit other dates. They add up differently around the different date of the embassy. ${ }^{10}$ Revisions in the dates of items directly connected to the embassy change the grounds from which indirectly connected dates can be determined. R. insists rightly that the chronological interrelationships of Synesius' corpus form a multifarious tangle, which can be fully unraveled only if the whole is addressed (p. 14). His most important contribution to the study of Synesius' letters is to have traced these intricate ties. Even though every line of connection must be retraced and reevaluated, R. well illuminates the complexity of the chronological problems. He provides a comprehensive basis for further examination.

R. faults earlier studies of Synesius' works not only for failing to address his whole corpus, but also for correlating items according to arbitrary and subjective criteria (p. 14). He makes some salutary corrections. For example, he rightly differentiates the count referred to but not named in Epistle 142 from the Paeonius to whom $\mathrm{De}$ dono is addressed. Synesius characterizes both as having broken down the "great walls" that too long separated the kindred pursuits of education or philosophy and military ability. ${ }^{11}$ This doublet is a good example of how a common rhetorical impulse behind two separate passages has produced a specious but false connection (cf. p. 14). In fact, Synesius regularly flatters the erudition of men from whom he seeks favors. ${ }^{12}$ As R. observes, he reuses standard phrases on several occasions (p. 80).

Yet R. himself elsewhere exploits the very fallacy he rebukes. He dates the brief recommendation Epistle 84 with Epistle 55 announcing the birth of Synesius' twin sons, merely because both begin with the same platitude that "a long letter accuses the bearer of poor acquaintance" (p. 174). But reliance on individual travelers to bear letters, and often more personal oral communication as well, ${ }^{13}$ must often have occasioned such remarks. Synesius indeed treats the tag as a truism: in both letters he immediately overturns it to reveal intimate friendship. There is no reason why even this way of revivifying the cliché should have occurred to him only once in

10. A striking example is R.'s treatment of Epist. 5 Garzya (=Epist. 4 Migne, Hercher), in which Synesius identifies the night between a Tuesday and a Wednesday on which a storm struck as also the night of a lunar conjunction and the "thirteenth of the waning month" (Epist. 5 p. 20. 7). R. calculates that between 395 and 415 , which he considers the outside limits for Synesius' correspondence, these calendaric and astronomical factors coincided no more than once a year and at widely differing times of year. He does not even bother to calculate possible dates in 400 or 401 , on the assumption that Synesius was then in Constantinople. Obviously the different date of Synesius' embassy would significantly reconfigure R.'s list of possible dates. This correction has already been discussed by Cameron, "Earthquake 400 ," p. 357. In fact, fundamental errors in astronomical calculation undermine the dates R. does consider. These problems exceed the scope of this review, however, for in his book (pp. 181-86) R. merely reasserts against C. Lacombrade, "Encore la lettre 4 de Synésios et sa nouvelle lune," REG 91 (1978): 564-67, the conclusions of the article in which he first considered this letter, "La lettre 4 de Synésios de Cyrène," REG 90 (1977): 263-95. I plan to treat the complex matter in detail in a separate article.

11. Epist. 142 p. 249. 6-9; Don. p. 134. 4-7; R., pp. 14-15, n. 13, pp. 79-82, against, e.g., PLRE II: $816-17$

12. Philosophy, the key term of Epist. 142 p. 249. 6-9 and Don. p. 134. 4-7, functions also in several examples R. does not cite: Epist. 26 p. 43. 2-3, 73 p. 130. 1-5, 118 p. 203. 8-10, 119 p. 205. 1, 131 p. 226. 5; see further A. Cameron and J. Long with a contribution by L. Sherry, Barbarians and Politics at the Court of Arcadius: Synesius' de Providentia (University of California Press, forthcoming), chap. III. 2 .

13. As Synesius says, lengthily, in Epist. 55; cf. Epist. 69, 84, 85, 106, 119 (most recommendation letters similarly imply further communication with the bearer about his own interests), 147; cf. further J. Matthews, "The Letters of Symmachus," in Latin Literature of the Fourth Century, ed. J. W. Binns (London and Boston, 1974), pp. 58-99, esp. p. 63 and n. 22 
his life. R. also connects Epistle 83 and Epistle 134 because in both Synesius ascribes obvious puns on friends' names to "Gorgianic frigidity" (pp. 148. 8-9, 234. 9; R., p. 174). This, too, scarcely need have been a unique, distinctive observation. Indeed Synesius' variation of tags in Epistles 82, 83, 84, 85, and 86, manifestly written at the same time to introduce the same person to several contacts in Alexandria, suggests that in contemporary letters Synesius took care not to repeat expressions. The whole group lacks stronger chronological indications. Yet R. never admits doubt where he can find a hint of a date. About Epistles 82-86, as about many other letters, he presents tenuous conclusions as definitely as the most secure, even against his own better principles.

R. stretches credibility when he identifies the unnamed count of Epistle 142 not only with a count mentioned but not named in Epistles 144 and 146 to the same addressee, Herculian, but also with another unnamed count in Epistles 98 and 99 to Olympius. His main ground is the fact that both groups of letters mention Hypatia, Ision, and an unnamed count (p. 78, n. 71, pp. 88, 107). But it is not strange that letters to two of Synesius' fellow-students at Alexandria should mention their teacher and a friend who was apparently another fellow-student. ${ }^{14}$ The two letters that mention Ision say that he is staying with Synesius, and Synesius separately tells both correspondents that he is planning to travel soon: these facts might seem to connect the letters in time. Yet Ision could have stayed with Synesius more than once. ${ }^{15}$ In Epistles 143 and 144 Synesius expects to depart on a definite date, the 20th of Mesore, and hopes that Herculian may join him in Cyrene before then (pp. 253. 5-6, 254. 19-20), whereas in Epistle 98 (which does not mention Ision) he is extremely ill but will leave for Alexandria as soon as he recovers (p. 166. 11-14). The travel plans are not irreconcilable, but neither do they match. R. typically ignores the emergency implied by Epistle 98 and makes 20 Mesore an absolute limit for all the letters (p. 110). The unnamed counts can link the letters only on a previous assumption that they are the same count: the argument for identifying them becomes perfectly circular. Moreover, Synesius and his friends treat the counts differently. Herculian must introduce Synesius to his count, who is being solicited for political reasons (Epist. 142 p. 249. 1-12, Epist. 144 p. 254. 1-12, 16-17, Epist. 146 p. 257. 12-20). On the other hand Synesius has written "many times already" to Olympius' count and seeks only to maintain the relationship (Epist. 98 p. 166. 6-9) and to recommend to him the poet Theotimus (Epist. 99 p. 167. 21). ${ }^{16}$ The differences might be reconciled by allowing Epistles 98 and 99 to have been

14. I would suggest that Ision is the fourth of the $\tau \varepsilon \tau \rho \alpha \kappa \tau u ̀ v ~ i \varepsilon \rho \tilde{\alpha} \varsigma \varphi \imath \lambda i \alpha \varsigma$ evoked in Epist. 143 p. 252.5 to Herculian, since he appears to be a dear friend both of Herculian (Epist. 144 p. 254. 15) and of Olympius (Epist. 99 p. 167. 19) as well as of Synesius himself; with less clear support from Synesius' works, Garzya, Synesii Cyrensis Epistulae, p. 252 nominates Isidore of Pelusium, some of whose letters address Synesius and who might be the unnamed deacon of Epist. 144 p. 254. 12-13 (cf. Garzya, p. 254, and ad Epist. 4 p. 8. 5).

15. Epist. 143 and 144 anticipate a visit by Herculian. Synesius invites other visitors at Epist. 97 p. 165. $5-7,123$ p. $212.3-7,126$ p. $215.9-12,134$ p. $232.12-18,139$ p. $242.13-14,149$ p. $267.15-268.3$. Epist. 36 p. $48.11-12,55$ p. $95.6-10,58$ p. $97.13-98.4,111$ p. $197.7-11$, and 114 p. $200.2-16$ concern visits of Synesius' family. Many letters imply some degree of visiting by the bearer, e.g., 13 p. 33. 14-34. 1,53 p. $95.3-6$.

16. A talented poet could confer palpable political advantages, so that this recommendation need not imply especial literary cultivation on the count's part: see A. Cameron, "Wandering Poets: A Literary Movement in Byzantine Egypt," Historia 14 (1965): 470-509 = Literature and Society in the Early Byzantine World (London, 1985), p. 1; D. T. Runia, “Another Wandering Poet," Historia 28 (1979): 254-56. 
written later than Epistles 142, 144, and 146 (a sudden fit of illness having postponed Synesius' original travel plans during one visit of Ision, or Synesius planning different journeys while Ision visited twice; or they are different counts), but R. prefers to play Procrustes for the sake of the calendar date. The letters might belong together, though R.'s false logic does not prove it; their text certainly refutes his dating.

R. nonetheless presses his conclusions even further. Synesius wrote Epistles 24, 28, and 130 to Simplicius, whom the Theodosian Code identifies as comes in 396-98; R. accordingly identifies his composite unnamed count as Simplicius. ${ }^{17}$ He derives an itinerary based on his interpretation of the letters, fitting them to his idea that in 398/99 Simplicius reorganized the military structure of Pentapolis (pp. 65-85). On the most favorable judgment, R.'s reconstruction is speculative and requires correction in some dates. The arbitrariness that promotes it, however, cannot inspire confidence.

In other arguments, R.'s quest for chronological precision forces him into cramped, implausible literalism. To determine a birth date for Synesius' eldest son Hesychius, for example, R. juxtaposes two short passages of the Dion (pp. 3745). In the first Synesius defines the uncharacterized second person to whom he has been addressing the essay as "the son I shall have later" (Dion p. 244. 7). In the second Synesius says that "the god promised [my son] for the new year, but the child is here with me already." ${ }^{18} \mathrm{R}$. quotes only these phrases. He concludes that Hesychius was born prematurely. Epistle 18 reports that Synesius begot all his children in Alexandria (p. 38. 1-2), suggesting that he wrote the Dion there. On the other hand, R. assumes that Synesius would not have written Epistle 154 explaining the Dion to Hypatia if he still remained in Alexandria to do so in person. Epistle 154 p. 271.7 says that the Dion was written "this year." R. deduces the following chain of events: Hesychius was born in mid-November, while Synesius was writing the Dion in Alexandria. Synesius finished the Dion and impregnated his wife again, then returned to Cyrene in time to send Epistle 154 back to Hypatia with the earlier De dono and his literary output for the ending year. R. harmonizes this sequence with the data of Epistles 123 and 133 to conclude that the year was 404 .

R. suggests that premature births weakened the health of all Synesius' children (p. 45), speciously justifying the strain that his hectic schedule imposes on the health and fertility of Synesius' wife. He cannot rightly claim support from Epistle 154: like the protheoria of De providentia, the letter justifies its existence regardless of location by commenting substantively on the essay. The one clearly demonstrable element in R.'s argument is wrong. He insists that $\pi \dot{\alpha} \rho \varepsilon \sigma \tau \iota v$ (Dion

17. Simplicius, PLRE II pp. 1013-14, which cites Synesius' letters by the numeration of Migne. The identification presumably underlies R.'s indemonstrable argument from silence, "aucun autre Comte n'est cité dans la Correspondance" (p. 107). It is Herculian's count who Synesius specifies has, like Simplicius

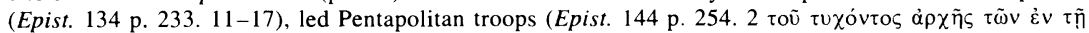

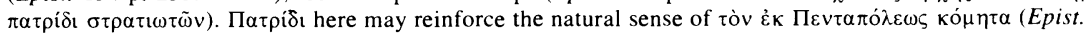
146 p. 257. 13), that the count himself is native to Pentapolis. R. implausibly takes this phrase to mean that the count recently left Pentapolis for Alexandria (p. 78, n. 70); I. Hermelin, Zu den Briefen des Bischofs Synesios (Uppsala, 1934), p. 25, to whom R. ascribes this interpretation, does not mention the phrase.

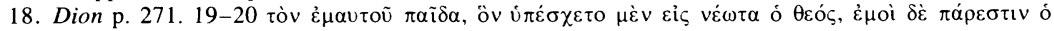
$\pi \alpha \tilde{i} \varsigma \tilde{\eta} \delta \eta$; the first passage is quoted more extensively below. 
p. 271. 20) must mean that Hesychius is literally, physically present as a separate

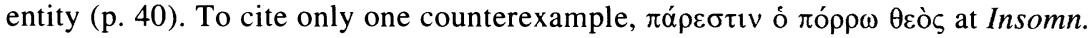
p. 167. 12 can only describe the imagined presence in dreams of "the god who is far off." 19 R. willfully disregards the context of the Dion when he presses this philological error. Synesius' discussion of literature has no relevance for a newborn baby. He imagines the child who will be, and will be able to read and learn; he does not need a real baby present to inspire him. Synesius says unambiguously that his child has not yet been born in the first passage $\mathrm{R}$. quotes. He marvels at himself, "already I wish to be with my child and to teach whatever occurs to me to think about each writer and work." 20 The second passage resumes this paternal fantasy. Synesius has just described how Socrates in Plato's Phaedrus uses playful as well as serious material for purposes of instruction; he now takes the example as a model for himself (Dion p. 272. $1 \dot{\alpha} \xi_{l} \tilde{\omega}$ ). Significantly, he says that Socrates does not really instruct Phaedrus, "for he is not a child but a youth or even a man already. But he posits an adolescent, fair and in the freshness of his age, and him he sways one way and the other about the concerns of desire." 21 The parallel locates Synesius' own true addressee in the same imaginary realm. This device reconciles the literal sense of the two passages. R. ignores the inconsistency and drops the first passage from consideration. ${ }^{22}$ In fact, only the first can be literally true. A birth was expected in the year after Synesius was working on the Dion. No evidence indicates when it actually took place. R. can narrow the chronological limits only by reading the text perversely.

Concerning Synesius' own date of birth R. observes that Synesius terms himself

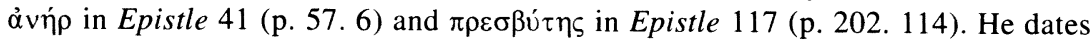
both letters to 412 . He accordingly concludes that Synesius passed his fortysecond birthday in that year, having been born in 370 (pp. 26-35). The argument depends on Synesius' using terms relating to age with strict calendar reference. Unprejudiced evaluation of R.'s examples, however, reveals only elastic developmental categories. ${ }^{23} \mathrm{R}$. makes them look more specific by translating each reference into a calendar age according to the seven-year increments of Censorinus. Nowhere does Synesius ever refer to this system, let alone adopt it. R. fails

19. Similarly the faculties of sense-perception $\pi \dot{\rho} \rho \varepsilon \sigma \tau$ in dreams (Insomn. p. 150. 14), and the dead

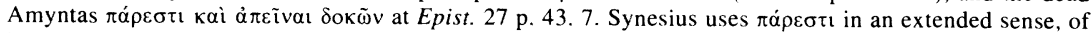
incorporeal subjects, at Epist. 79 p. 144. 20, 100 p. 168. 11, 101 p. 170. 7, Insomn. pp. 155. 14, 170. 23, 176. 6, 177. 2, and with an infinitive at Epist. 134 p. 233. 13. Indeed Synesius never uses the verb of simple physical presence.

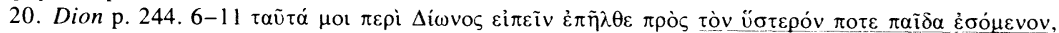

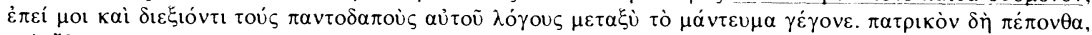

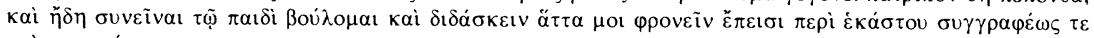

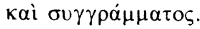

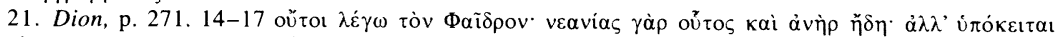

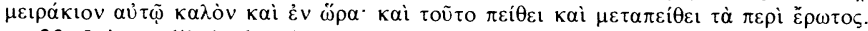

22. It is not likely that the passages reflect different stages in the composition of the Dion. The essay itself shows no other signs of interruption, and Synesius in Epist. 154 implies nothing but continuous composition. The protheoria of Prov. demonstrates that he did take care to explain inconsistencies that circumstances imposed on a finished work. In spiteful italics R. charges that H. Druon (Oeuvres de Synésios [Paris, 1878], p. 341) blurs the literal sense of the second passage in his translation because he wished to protect his chronology for Synesius' life, unjustly (p. 40, n. 25): a notable case of the pot calling the napery black.

23. R. admits that Synesius does not always distinguish véo $\zeta$ and $\mu \varepsilon \iota \rho \dot{\kappa} \kappa ı$, though he proceeds to do

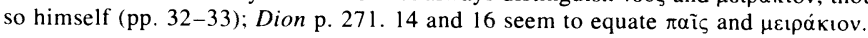


signally to legitimate his imposition by asserting that Censorinus' emphasis on "le caractère philosophique et médical . . . n'a pu échapper au Cyrènéen, fervent disciple de Platon ... " only four sentences after remarking that Plato used a system of nine-year increments (p. 30). Moreover, in Epistle $117 \pi \rho \varepsilon \sigma \beta u ́ \tau \eta \varsigma$ plays on a Homeric tag that Synesius uses to trigger his apology (Il. 21. 439; cf. Epist. 142 p. 249. 3). Its rhetorical aptness further blurs its chronological specificity. R. claims that his philological argument confers new certainty on the traditional consensus, which has always seen 370 within the range of probability for Synesius' birth date (p. 35; cf. pp. 21-23); but rigidly and regardless of context to impose an alien specificity on an author who uses terminology flexibly is spurious philology.

The same tendencies characterize the whole of R.'s book. Excessive precision flaws even his best considerations, such as his consistent regard for the constraints of the sailing season. Modern scholars must always remember how weather regulated transportation of the ancient world. Yet it is not credible that every letter R. dates to the beginning of the year was sent in March. ${ }^{24}$ There is not space here to reexamine all R.'s data and to reestablish better dates. This task remains to be performed by scholars who wish to pursue a close chronology of Synesius' life and works: rightfully a large group. R. pushes his inquiry to new extremes of precision and detail. Regrettably his model must often be judged more cautionary than exemplary; but only with regard to both the potentialities and the limitations of chronological research can knowledge be advanced. ${ }^{25}$

\section{Jacqueline Long}

The University of Texas at Austin

24. E.g., Epist. 49, 91, 118, 119, 123: R., pp. 215-16. See L. Casson, Ships and Seamanship in the Ancient World (Princeton, 1971), pp. 270-73: Vegetius 4. 30 considers navigation safest between 27 May and 14 September, and identifies less safe but acceptable periods stretching beyond these limits to 10 March and 10 November. On the other hand, urgent imperial shipping was undertaken even in winter months. And for many purposes land travel remained possible.

25. I note the following minor errors: p. 38: "5, 95, 10-11" should be " $55,95,10-11$ "; p. 127, n. 75 : "l'antériorité de 71 sur 48 " should be “. . . sur 50" (50 Garzya = 48 Migne and Hercher); p. 128: "les lettres 71 et 48 " should be ". . 71 et 50"; p. 211, n. 20: "PLRE I s.v. Aurelianus 2" should be “... Aurelianus 3"; p. 238: “Aurélien, le successeur du Préfet du Prétoire Eutrope" should be "Aurélien, le Préfet du Prétoire après la chute du tout-puissant Praepositus Sacri Cubiculi Eutrope": see PLRE II, s.v. Eutropius 1, pp. 440-44; p. 238: "d'août 399 à novembre 400 " by R.'s argument should be ". . . à novembre 399" (cf. p. 211); R. follows the argument of A. H. M. Jones (JRS 54 [1964]: 78-89= Roman Economy [Oxford, 1974], pp. 375-95); see, however, Barnes, "Synesius," and Cameron and Long, Barbarians and Politics; p. 238, n. 16, p. 238, n. 18, p. 246, n. 55: "PLRE I s.v. Aurelianus 6" should be ". . . Aurelianus 3." 